\section{Evaluation of Epicotyl Grafting on 25- to 55-day-old Pecan Seedlings}

\author{
Rui Zhang ${ }^{1}$, Fang-Ren Peng ${ }^{1,3}$, Dong-Liang Le ${ }^{1,2}$, \\ Zhuang-Zhuang Liu ${ }^{1}$, Hai-Yang $\mathrm{He}^{1}$, You-Wang Liang ${ }^{1}$, \\ Peng-Peng Tan ${ }^{1}$, Ming-Zhuo $\mathrm{Hao}^{1}$, and Yong-Rong $\mathrm{Li}^{2}$
}

AdDITIONAL INDEX wORDs. Carya illinoinensis, propagation, scion, grafting tape, grafting time

Summary. Scion wood of 'Caddo' and 'Desirable' pecan (Carya illinoinensis) was grafted onto the epicotyl of 1-month-old, open-pollinated 'Shaoxing' pecan seedlings for evaluation as a grafting technique to reduce the time to produce grafted trees. The results showed that seedlings grafted with "base scions" had higher survival than those grafted with "terminal scions" for both 'Caddo' and 'Desirable'. Also, grafting with paraffinic tape could achieve greater success rate than that with medical tape. The most ideal time to perform this grafting was late April in Nanjing, China, when pecan seedlings were about 35 days old. This study demonstrated that the technique yielded successful epicotyl grafting of $>70 \%$, and it could thus be applied in practice.

$\mathrm{P}$ ecan is a highly heterozygous outcrossing species, which shows wide variation in nut and tree quality when propagated from seed (Sparks, 2005). Establishment of orchards of superior genotypes is critical for pecan as a cultivated crop. Much research has been conducted for pecan propagation, such as clonal propagation by stem cuttings (McEachern and Storey, 1972; Wolstenholme and Allan, 1975), root cuttings (Nelson and Gustafson, 1982), mound layering (Wood, 1989), in vitro propagation (Avila-Trevino et al., 2013; Corteolivares et al., 1990; Hansen and Lazarte, 1982, 1984; Renukdas et al., 2010), and grafting and budding (Wood et al., 1994). Since propagation by tissue culture or vegetative cuttings has not been perfected, the commercial pecan industry is still dependent on conventional propagation by grafting and budding (Nesbitt et al., 2002).

Currently, four main grafting and budding techniques have been commonly used, including whip grafting, inlay bark grafting, four-flap

Thanks to the Priority Academic Program Development of Jiangsu Higher Education Institutions (PAPD) and the Special Fund for Forest Scientific Research in the Public Welfare (201304711) for financial assistance.

${ }^{1}$ College of Forestry, Nanjing Forestry University, Nanjing 210037, China

${ }^{2}$ Nanjing Green Universe Pecan Science and Technology Co. Ltd., Nanjing 210007, China

${ }^{3}$ Corresponding author. E-mail: frpeng@njfu.edu.cn. grafting, and patch budding (Wells, 2007). The successful use of these grafting and budding techniques proved to be a milestone for the pecan industry (Wood et al., 1994). Fourflap grafting is ideal for small diameter rootstocks and branches of larger trees (Taylor and Drews, 1983). Rootstocks of 1,2 , and 3 years old with diameter up to $2.5 \mathrm{~cm}$ may be grafted by whip grafting (Wells, 2007). Patch budding may be used on small tree trunks or branches 0.9 to $3.8 \mathrm{~cm}$ in diameter (McCraw, 2007). Inlay bark grafting is often used for rootstocks that are too large for other grafting techniques (Drews et al., 1981). The disadvantage with all of these, however, is that the seedlings generally require two to three seasons of growth before their diameter is large enough to be grafted or budded, thus increasing the cost of the product and tying up land in the nursery.

Grafting performed on germinated seeds has proven to be successful in other fruit crop trees, such as chestnut [Castanea sativa (Serdar, 2009)], mango [Mangifera indica
(Kaur and Malhi, 2006)], nutmeg [Myristica fragrans (Haldankar et al., 1999)], and walnut [Juglans regia (Gandev and Arnaudov, 2011; Suk-In et al., 2006)]. The objective of this study was to test if epicotyl grafting can be an alternative, short-term reproduction method to produce grafted pecan trees.

\section{Material and methods}

SeEd Stratification. The test was established at Nanjing Green Universe Pecan Nursery in Nanjing, China (lat. $32.05^{\circ} \mathrm{N}$, long. $118.77^{\circ} \mathrm{E}$ ). Open-pollinated seeds of the Chinese selection 'Shaoxing' were used as the seed stock to produce seedlings. 'Shaoxing' had a small nut of very good quality with $\approx 50 \%$ percentage fill. Seeds were averaged $30.38 \mathrm{~mm}$ in length, $20.93 \mathrm{~mm}$ in width, and $5.39 \mathrm{~g}$ in weight. Seeds were collected on 7 Nov. 2013, air-dried for 7 d, packed in polyethylene bags and then stored at $4{ }^{\circ} \mathrm{C}$ before treatment initiation. On 7 Jan. 2014, seeds were soaked in running cold water for $48 \mathrm{~h}$ and then stratified in moist sand at $5 \pm 2{ }^{\circ} \mathrm{C}$ for $60 \mathrm{~d}$, after which seeds were transferred to the medium ( 5 peat: 3 vermiculite: 2 perlite by volume; Shanghai Jizhi Agricultural Science and Technology Co., Shanghai, China) at $30{ }^{\circ} \mathrm{C}$ in the greenhouse to initiate germination. On 15 Mar. 2014, 1500 germinated seeds with hypocotyl less than $0.5 \mathrm{~cm}$ were selected for the experiment. Seeds were placed into 2 - $\mathrm{m}$-wide bed covered with $10 \mathrm{~cm}$ of medium (5 peat:3 vermiculite: 2 perlite by volume).

ROOTSTOCK PREPARATION. From mid-April, 25- to 55-d-old seedlings were used as rootstock. The diameter of epicotyls was 2 to $3 \mathrm{~mm}$. Seedlings were dug from the medium in the greenhouse, and medium was cleaned from around the epicotyl (Fig. lA).

Scion collection. Dormant, 15-cm-long, 1-year-old scions of 'Caddo' and 'Desirable' pecan were collected at Nanjing Green Universe

\begin{tabular}{llll}
\hline $\begin{array}{l}\text { Units } \\
\text { To convert U.S. to SI, } \\
\text { multiply by }\end{array}$ & U.S. unit & SI unit & $\begin{array}{l}\text { To convert SI to U.S., } \\
\text { multiply by }\end{array}$ \\
\hline 0.3048 & $\mathrm{ft}$ & $\mathrm{m}$ & 3.2808 \\
3.7854 & gal & $\mathrm{L}$ & 0.2642 \\
2.54 & inch(es) & $\mathrm{cm}$ & 0.3937 \\
25.4 & inch $(\mathrm{es})$ & $\mathrm{mm}$ & 0.0394 \\
$\left({ }^{\circ} \mathrm{F}-32\right) \div 1.8$ & ${ }^{\circ} \mathrm{F}$ & ${ }^{\circ} \mathrm{C}$ & $\left({ }^{\circ} \mathrm{C} \times 1.8\right)+32$
\end{tabular}



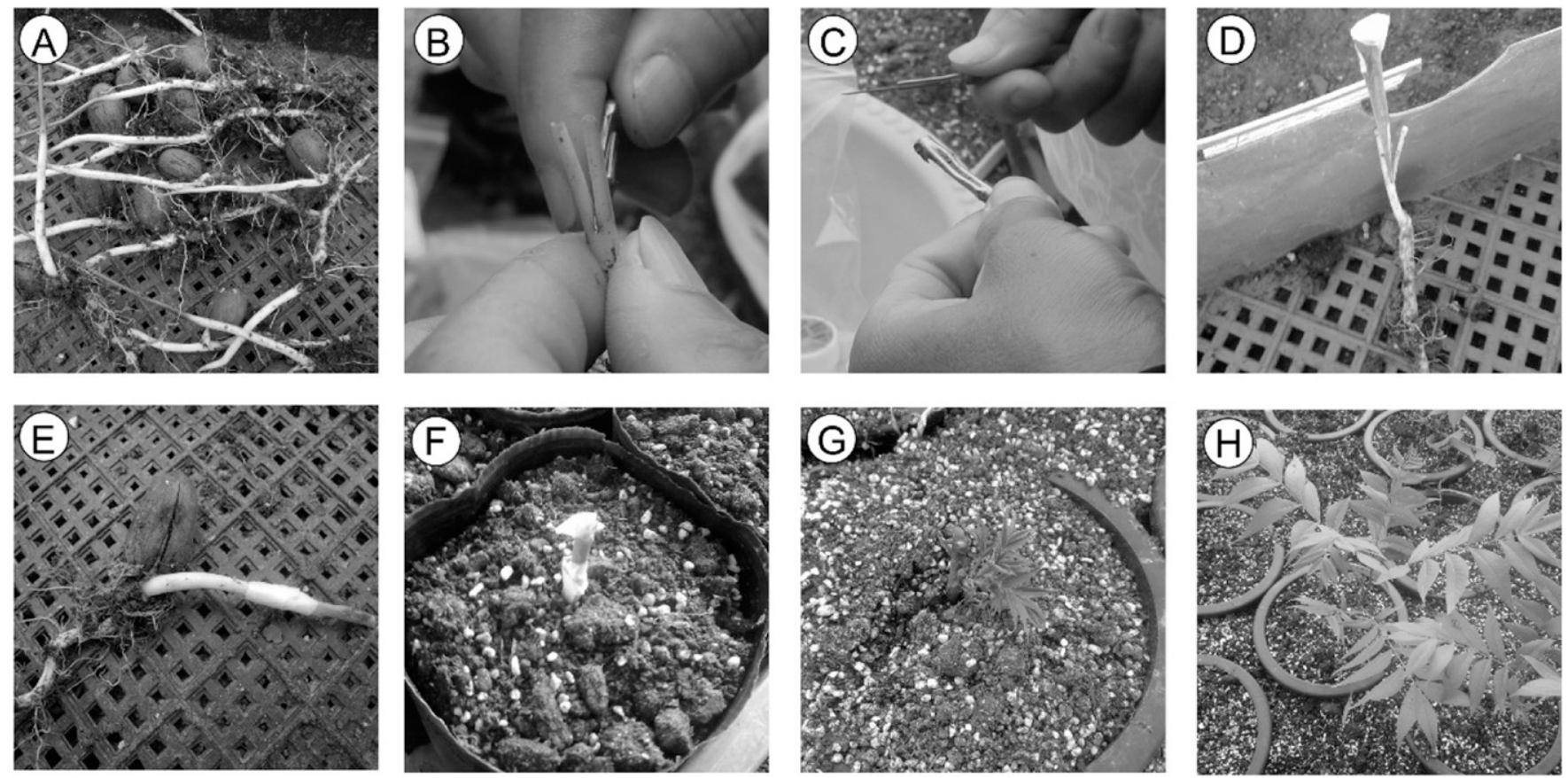

Fig. 1. Procedures of epicotyl grafting in pecan. (A) Seedlings (10 Apr.) that were 2 to $3 \mathrm{~mm}(0.08$ to 0.12 inch) in diameter. (B) Splitting the center of the epicotyl. (C) Sloping cut through the scion on both sides. (D) Fitting and inserting the scion. (E) The completed graft. (F) New graft in the container. (G) $45 \mathrm{~d}$ and (H) $65 \mathrm{~d}$ after grafting.

Pecan Nursery in mid-Feb. 2014. Each scion stick had at least four plump, healthy buds and was 2 to $3 \mathrm{~mm}$ in diameter to match the diameter of the seedling epicotyl. Scions were cut at the center and sealed in separate polyethylene bags marked for "terminal scions" and "base scions," respectively. Scions were stored at $5{ }^{\circ} \mathrm{C}$ until used for grafting.

Tools. A pair of scissors, a grafting knife, and two types of grafting tape were used for grafting. Considering that the grafting was carried out on very small seed stocks, we used two self-adhesive grafting tapes: BuddyTape (Aglis \& Co., Fukuoka, Japan), a paraffinic tape that can be stretched over the whole bud after grafting, and medical tape (Shanghai Medical Instruments, Shanghai, China), a silky, breathable, and adhesive tape.

GRAFTING PROCEDURES. First, the rootstock was cut off smoothly above the epicotyl. Then the center of the epicotyl was split $2 \mathrm{~cm}$ deep with a grafting knife (Fig. 1B). Third, the scion that was about the same diameter as the rootstock was selected, and was slopingly cut through both sides, $2 \mathrm{~cm}$ from the lower end (Fig. IC). Fourth, the scion was fitted and inserted on the stock (Fig. 1D). Fifth, the cut area and the scion were wrapped with grafting tape to seal the cuts and scion (Fig. 1E). Finally, the completed graft was transferred to a $15 \times 20-\mathrm{cm}$ container with one or two buds exposed (Fig. IF). The containers were placed in full sun on a concrete floor of the greenhouse. The grafted seedlings were irrigated with micro irrigation system $\left(80 \mathrm{~L} \cdot \mathrm{h}^{-1}\right)$ for $\mathrm{l} h$ twice per day. The water came from the natural river nearby.

EXPERIMENT DESIgN. Experiment one was conducted on 10,20 , and 30 Apr. and 10 May 2014 to determine the effect of grafting time on the grafting survival. The base of 'Caddo' and 'Desirable' scions were grafted onto the 'Shaoxing' rootstocks with paraffinic tape. An additional experiment was set up on 20 Apr. to examine effects of grafting with the different positions of scions (base and terminal) and different types of grafting tapes (paraffinic and medical tapes) on the survival of epicotyl grafts. Treatments were arranged in a randomized block design with four replications per treatment. Each replication consisted of 20 seedlings. The number of graft failures, rootstock deaths, and successful grafts and the stem height and diameter of live trees was investigated on 1 Nov. Data were subjected to analysis of variance, where applicable means were separated using Fisher's least significant difference (LSD) test at $P \leq 0.05$ using SAS software (version 9.3; SAS Institute, Cary, NC). To evaluate the effect of grafting time on pecan graft survival, we drew a scatterplot with grafting data and survival percent as $x$ - and $y$ axes, respectively. Then we added the trend line.

\section{Results}

Successful grafted seedlings began to sprout 40 to $45 \mathrm{~d}$ after grafting (Fig. 1G). Graft survival was influenced by cultivars of scions. Generally, grafts with 'Desirable' scion had greater success than those with 'Caddo' scions for 10 Apr. and 20 Apr. (Table 1). Approximately 3.96\% to $8.77 \%$ died because of failed grafting onto epicotyl pecans (Table 1). The grafting success was significantly affected by the grafting date. Seedlings grafted on 20 Apr., when rootstocks were $35 \mathrm{~d}$ old, achieved the maximum success for grafts with 'Caddo' (70.51\%) and 'Desirable' $(87.13 \%)$ scions (Table 1). However, graft survival decreased when seedlings were grafted later on $30 \mathrm{Apr}$. and 10 May. Also, early grafting carried out on 10 Apr. resulted in 
Table 1. Effect of time of grafting on 'Caddo' and 'Desirable' pecan base scions propagated by grafting on epicotyls. 'Shaoxing' pecan was used as rootstock. Paraffinic tape was used for the grafting. Each data point is the average of four replications of 20 seedlings.

\begin{tabular}{|c|c|c|c|c|c|}
\hline Grafting date & Age of rootstock (d) & Cultivar of scion & Failure $^{\mathrm{z}}(\%)$ & Death $^{\mathrm{y}}(\%)$ & Survival $^{\mathrm{x}}(\%)$ \\
\hline \multirow[t]{2}{*}{10 Apr. } & 25 & Caddo & $72.41 \mathrm{a}^{\mathrm{w}}$ & $6.90 \mathrm{a}$ & $20.69 \mathrm{e}$ \\
\hline & & Desirable & $57.14 \mathrm{a}$ & $4.76 \mathrm{a}$ & $38.10 \mathrm{~d}$ \\
\hline & & Desirable & $8.91 \mathrm{c}$ & $3.96 \mathrm{a}$ & $87.13 \mathrm{a}$ \\
\hline \multirow[t]{2}{*}{30 Apr. } & 45 & Caddo & $29.82 \mathrm{~b}$ & $8.77 \mathrm{a}$ & $61.41 \mathrm{c}$ \\
\hline & & Desirable & $32.39 \mathrm{~b}$ & $8.45 \mathrm{a}$ & $59.16 \mathrm{c}$ \\
\hline
\end{tabular}

${ }^{\mathrm{z}} \mathrm{Graft}$ failed, but rootstocks still survived.

${ }^{y}$ Rootstocks died after failed grafting.

${ }^{x}$ Seedling were successfully grafted.

"Means within cultivar followed by different letters are significantly different at $P \leq 0.05$ by Fisher's least significant difference (LSD) test.

lower graft survival rate, which was $20.69 \%$ and $38.10 \%$ for 'Caddo' and 'Desirable' scion, respectively (Table 1; Fig. 2).

Grafting with two different tapes was carried out on 20 Apr. 2014. There was significant difference in graft survival between grafting with these two tapes. Results showed that both grafts with 'Caddo' and 'Desirable' scion obtained significant higher graft survival with paraffinic tape than those with medical tape (Table 2). Graft survival was also influenced by the different position of scion that was used for grafting. Seedlings grafted with "base scions" had higher survival than those grafted with "terminal scions" (Table 2).

Plant height and diameter of the plants were recorded at the end of the first growing season (Table 3). Plant height and stem diameter data indicated the great variation in the growth rate of different cultivars. Height was greater on 'Caddo' pecan $(35.3 \mathrm{~cm})$ than 'Desirable' pecan $(22.50 \mathrm{~cm})$, while 'Desirable' pecan $(1.01 \mathrm{~cm})$ had greater diameter than that of 'Caddo' pecan $(0.78 \mathrm{~cm})$. For those seedling in which grafting failed, height and diameter were 31.33 and $0.88 \mathrm{~cm}$, respectively.

\section{Discussion}

Graft survival was affected by the time of scion insertion. Nesbitt et al. (2002) suggested that a success rate of $75 \%$ or higher is considered good in the pecan industry, when numerous trees are propagated at one time. In this study, the most suitable time for making grafts onto the epicotyl of pecans was in late April (Fig. 2). Abrupt changes in graft survival may

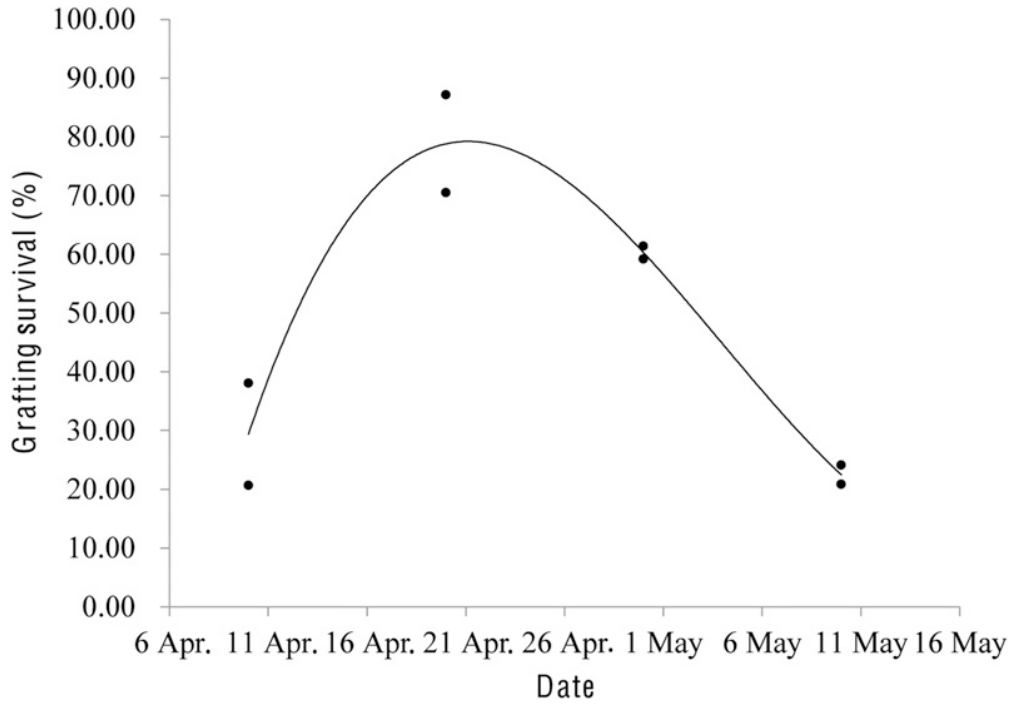

Fig. 2. Effect of grafting time on pecan graft survival. Each data point is the average of four replications of 20 grafts. The relationship of graft survival to grafting time is described by equation $\mathrm{Y}=\mathrm{ax}^{3}+\mathrm{bx}^{2}+\mathrm{cx}+\mathrm{d}$, where $\mathrm{a}=0.0081, \mathrm{~b}=-1016.9, \mathrm{c}=$ $4 \mathrm{E}+07$ and $\mathrm{d}=-6 \mathrm{E}+11 . \mathrm{R}^{2}=0.9337$.

Table 2. Effects of grafting with the different positions of scions (base and terminal) and different types of grafting tapes (paraffinic tape and medical tape) on the survival of epicotyl grafts. 'Shaoxing' pecan was used as rootstock. Grafting was carried out on 20 Apr. 2014.

\begin{tabular}{lccc}
\hline Cultivar of scion & Position of scion & Tape type $^{\mathrm{z}}$ & Survival (\%) $^{\mathrm{y}}$ \\
\hline Caddo & Terminal & $\mathrm{P}$ & $20.28 \mathrm{~d}^{\mathrm{x}}$ \\
& & $\mathrm{M}$ & $5.25 \mathrm{e}$ \\
& Base & $\mathrm{P}$ & $71.24 \mathrm{~b}$ \\
Desirable & Terminal & $\mathrm{M}$ & $17.81 \mathrm{~d}$ \\
& & $\mathrm{P}$ & $26.83 \mathrm{c}$ \\
& Base & $\mathrm{M}$ & $7.33 \mathrm{e}$ \\
& & $\mathrm{P}$ & $87.67 \mathrm{a}$ \\
& & $\mathrm{M}$ & $21.28 \mathrm{~d}$ \\
\hline
\end{tabular}

${ }^{\mathrm{z}} \mathrm{P}=$ paraffinic tape $\mathrm{M}=$ medical tape

yseedling were successfully grafted.

${ }^{x}$ Means within cultivar followed by different letters are significantly different at $P \leq 0.05$ by Fisher's least significant difference (LSD) test.

be a result of varying factors, such as prevailing temperatures (Yates and Sparks, 1992) and undeveloped root system of young seedlings with less reserved cotyledonal lipids (Wetzstein et al., 1983), other than time.

This current experiment also showed that failed grafting onto 
Table 3. First-year stem height and diameter of 'Desirable' and 'Caddo' pecan that were grafted onto the epicotyl of 'Shaoxing' pecan seedlings. On 1 Nov. 2014, stem height was measured from the soil line to the growing point, while stem diameter was measured with Vernier caliper at a point $2.5 \mathrm{~cm}$ above the soil line. Each data is the average of four replications of 20 seedlings.

\begin{tabular}{lcc}
\hline Cultivar of scion & Ht $(\mathrm{cm})^{\mathrm{z}}$ & Caliper $(\mathrm{cm})$ \\
\hline Desirable & $22.50 \mathrm{c}^{\mathrm{y}}$ & $1.01 \mathrm{a}$ \\
Caddo & $35.33 \mathrm{a}$ & $0.78 \mathrm{c}$ \\
Shaoxing $^{\mathrm{x}}$ & $31.33 \mathrm{~b}$ & $0.88 \mathrm{~b}$ \\
\hline
\end{tabular}

${ }^{\mathrm{z}} 1 \mathrm{~cm}=0.3937$ inch.

y Means within column followed by different letters are significantly different at $P \leq 0.05$ by Fisher's least significant difference test (LSD).

${ }^{x}$ Graft failed, but rootstocks survived.

epicotyl of pecans only caused a small amount of seedling mortality $(<10 \%)$ and did not have severe effects on stem growth. Therefore, these seedlings could be subjected to one of the more traditional grafting methods the following year. The diameter of failed grafted seedlings reached $0.88 \mathrm{~cm}$ at the end of the first growing season, which was large enough for whip grafting and patch budding (McCraw, 2007; Wells, 2007).

The grafting success was much lower for the seedlings grafted with medical tape than for treatment with paraffinic tape. This may be because the medical tape did not provide a waterproof barrier, which Lipetz (1970) suggested may be a prerequisite for wound healing. There were some advantages with respect to using paraffinic tape. The advantages include the fact that paraffinic tape is a paraffinic strip that can be stretched over the whole graft union for a complete cover, and it acts as a mechanical barrier preventing the scion from drying out, hence improve grafting survival. Furthermore, it allows for easy and rapid application. With paraffinic tape, the grafter working $8 \mathrm{~h}$ per day could graft $\approx 300$ seedlings. However, the disadvantage associated with paraffinic tape was its high cost (\$25 per 40-m roll).

The position of the portion of scion that was used for grafting also affected the graft survival. Grafting with the terminal end of the shoots achieved less success, though they were as thin as the epicotyl rootstock in diameter. Results of this study were consistent with previous reports by Wells (2007), who suggested scions cut from the end of the shoot should be avoided since the buds are often immature and may be damaged by cold.
A potential disadvantage of grafting onto epicotyl of pecan is the damage to the young scions by cold injury following the grafting. Sparks and Payne (1977) demonstrated that scions grafted at ground level were much more likely to suffer cold injury than seedling stems.

Investigation of the shoot growth of the successfully grafted seedlings at the end of the first growing season indicated that there was significant difference between different cultivars. Seedlings with 'Caddo' scions had greater height, while those with 'Desirable' scions had greater diameter. Furthermore, the leaves generated on the scion during the growing season following the grafts were pinnate with more leaflets (Fig. $1 \mathrm{H}$ ), while for the juvenile seedlings, leaves formed in the first season were simple. Sparks (2005) demonstrated that leaf number of 'Curtis' seedlings seemed to be predetermined at a maximum of 11 to 13 leaves per seedling the first year. This increase in the number of leaves of grafted pecan seedlings may increase the rate of photosynthesis, and hence increase growth.

\section{Conclusions}

This study demonstrated that the epicotyl grafting technique could be applied on pecans, which could reduce the time needed to produce a grafted tree. It also appeared that failed grafting did not severely affect shoot growth. The most ideal time to perform this grafting was late April in Nanjing, China, when pecan seedlings were about $35 \mathrm{~d}$ old. Grafting with paraffinic tape could achieve greater success rate than that with medical tape. However, further studies would be required to evaluate other alternative grafting tapes to reduce the cost. Scions cuts from the base of the shoot were suggested for grafting to obtain a higher graft survival. The longterm value of pecan propagation by epicotyl grafting is yet to be determined.

\section{Literature cited}

Avila-Trevino, J.A., J.G. Arreola-Avila, J.L. Rodriguez-de la O, R. Trejo-Calzada, D. Valdez-Cepeda, and A. Borja-de la Rosa. 2013. Morphogenic response in the in vitro propagation of pecan (Carya illinoinensis [Wangenh] K. Koch). Revsta Chapingo Serie Ciencias Forestales y del Ambiente 19:469-481.

Corteolivares, J., G.C. Phillips, and S.A. Butlernance. 1990. Micropropagation of pecan. HortScience 25:1308

Drews, D., J.B. Storey, and G.R. Mceachern. 1981. A comparison of pecan inlay bark grafting procedures. HortScience 16:283.

Gandev, S. and V. Arnaudov. 2011. Propagation method of epicotyl grafting in walnut (Juglans Regia L.) under production condition. Bulgarian J. Agr. Sci. 17:173-176.

Haldankar, P.M., D.D. Nagwekar, A.G. Desai, and J.C. Rajput. 1999. Factors influencing epicotyl grafting in nutmeg. J. Medicinal Aromatic Plant Sci. 21:940944.

Hansen, K.C. and J.E. Lazarte. 1982. Invitro-propagation of pecan (Carya illinoinensis). HortScience 17:487-487.

Hansen, K.C. and J.E. Lazarte. 1984. Invitro-propagation of pecan seedlings. HortScience 19:237-239.

Kaur, G. and C. Malhi. 2006. Effect of age of rootstock and growing medium on the success of epicotyl grafting in mango. Indian J. Hort. 63:244-247.

Lipetz, J. 1970. Wound-healing in higher plants. Intl. Rev. Cytol. 27:1-28.

McCraw, D. 2007. Patch budding pecans. Div. Agr. Sci. Natural Resources Oklahoma Coop. Ext. Serv. 6206.

McEachern, G. and J. Storey. 1972. Pecan clonal rootstock propagation techniques. Pecan Qrtly. 6:5-7.

Nelson, K.L. and W. Gustafson. 1982. A propagation technique for producing clonal rootstocks of pecan, Carya illinoensis(Wang) K. Koch, by root cuttings. Annu. Rpt. Northern Nut Growers Assn. 73:134-137.

Nesbitt, M.L., W.D. Goff, and L.A. Stein. 2002. Effect of scionwood packing moisture and cut-end sealing on pecan 


\section{Preliminary and Regional Reports}

graft success. HortTechnology 12:257260.

Renukdas, N.N., M. Manoharan, and J.O. Garner. 2010. In vitro propagation of pecan [Carya illinoinensis (Wangenh) K. Koch]. Plant Biotechnol. 27:211-215.

Serdar, U. 2009. Grafting in seeds, radicles, hypocotyls and epicotyls of chestnut. Acta Hort. 815:199-204.

Sparks, D. 2005. Adaptability of pecan as a species. HortScience 40:1175-1189.

Sparks, D. and J. Payne. 1977. Freeze injury susceptibility of non-juvenile trunks in pecan. HortScience 12:497-498.

Suk-In, H., L. Moon-Ho, and J. YongSeok. 2006. Study on the new vegetative propagation method 'Epicotyl grafting' in walnut trees (Juglans spp.). Proc. Fifth Intl. Walnut Symp. 705:371-374.

Taylor, G. and D. Drews. 1983. The four flap graft: A dependable technique for the grafting of smaller diameter pecan stocks. Pecan Qrtly. 17:6-9.

Wells, L. 2007. Pecan propagation, p. 9-18. In: L. Wells and P. Conner (eds.) Southeastern pecan growers' handbook. Univ. Georgia Coop. Ext. Bul. 1327.

Wetzstein, H.Y., D. Sparks, and G.A. Lang. 1983. Cotyledon detachment and growth of pecan seedlings. HortScience 18:331-333.
Wolstenholme, B. and P. Allan. 1975. Progress and problems in pecan clonal propagation by stem cuttings. Gewasproduksie Crop Production 4:29-32.

Wood, B.W. 1989. Clonal propagation of pecan by mound layering. HortScience $24: 260-262$

Wood, B.W., J.A. Payne, and L.J. Grauke. 1994. An overview of the evolution of the US pecan industry, p. 1-11. In: C.R. Santerre (ed.). Pecan technology. Springer, New York, NY.

Yates, I.E. and D. Sparks. 1992. Pecan cultivar conversion by grafting onto roots of 70-year-old trees. HortScience 27:803-807. 